\title{
PENINGKATAN KETERAMPILAN MENULIS ARGUMENTASI MELALUI MODEL THINK PAIR SHARE DAN MEDIA AUDIOVISUAL PADA SISWA KELAS X-10 SMA NEGERI KEBAKKRAMAT
}

\section{IMPROVING ARGUMENTATION WRITING SKILL THROUGH THINK PAIR SHARE MODEL USING AUDIOVISUAL MEDIA FOR STUDENTS X-10 GRADE OF SMA NEGERI KEBAKKRAMAT}

\author{
Fitria Cahyaningrum, Andayani, Kundharu Saddhono \\ Pascasarjana Universitas Sebelas Maret \\ Jl. Ir. Sutami No. 36 A, Kentingan, Surakarta \\ E-mail: fitriac41@gmail.com, bu_anda09@yahoo.com, kundharu.uns@gmail.com
}

Naskah diterima tanggal: 11-01-2018, disetujui tanggal: 21-05-2018

\begin{abstract}
This research aims to improve learning process quality of writing argumentation text and argumentation writing skills through the Think Pair Share model with audiovisual media of students $X-10$ grade SMA Negeri Kebakkramat. This research was a Classroom Action Research (CAR) with two cycles. Data sources include events, informants, and documents. Data collection through interviews, observation, and document analysis. Data validity by triangulation method technique, triangulation of data source and informant review. Data analysis technique using comparative descriptive analysis technique. Think Pair Share model with audiovisual is able to improve the quality of learning process of argumentation writing skill indicated by teacher and student performance. In pre-cycles, the teacher and student performance values were still below the achievement indicator. In cycle I, the value of teacher performance increased to 69.29 and the percentage of student performance of $47.22 \%$. Meanwhile, in cycle II the teacher performance value became 80.71 and the percentage of student performance became $78.95 \%$. After the action done on the first cycle, there were only 21 students who achieved the value of KKM (minimum completeness criteria) which means it did not meet the achievement indicators. Implementation of Think Pair Share with audiovisual media in cycle II showed a significant improvement in argumentation writing skill, that is, score of 31 students exceeded KKM. In conclusion, the application of Think Pair Share model with audiovisual media is able to improve learning process quality and argumentation writing skill for the tenth grade students of SMA Negeri Kebakkramat.
\end{abstract}

Keyword: writing argumentation, think pair share, audiovisual media

Abstrak: Penelitian ini bertujuan untuk meningkatkan kualitas proses pembelajaran menulis argumentasi dan keterampilan menulis argumentasi melalui penerapan model Think Pair Share dengan media audiovisual siswa kelas X-10 SMA Negeri Kebakkramat. Penelitian ini adalah Penelitian Tindakan Kelas dengan dua siklus. Sumber data berupa peristiwa, informan, dan dokumen. Pengumpulan data melalui wawancara, observasi, dan analisis dokumen. Validitas data dengan teknik triangulasi metode, triangulasi sumber data dan review informan. Teknik analisis data menggunakan teknik analisis deskriptif komparatif. Model Think Pair Share dengan audiovisual mampu meningkatkan kualitas proses pembelajaran keterampilan menulis argumentasi dengan indikator kinerja guru dan siswa. Pada prasiklus, nilai kinerja guru dan siswa masih berada di bawah indikator pencapaian. Siklus I, nilai kinerja guru meningkat menjadi 69,29\% dan kinerja siswa sebesar 47,22\% sedangkan pada siklus II nilai kinerja guru menjadi $80,71 \%$ dan kinerja siswa menjadi $78,95 \%$. Setelah dilakukan 
tindakan pada siklus I, siswa yang tuntas hanya 21 siswa yang artinya dianggap belum memenuhi indikator pencapaian. Penerapan Think Pair Share dengan media audiovisual pada siklus II, menunjukkan peningkatan signifikan pada keterampilan menulis argumentasi, yaitu skor 31 siswa melampaui KKM. Disimpulkan bahwa penerapan model Think Pair Share dengan audiovisual mampu meningkatkan kualitas proses dan keterampilan menulis argumentasi pada siswa kelas $X$ SMA Negeri Kebakkramat.

Kata kunci: menulis argumentasi, Think Pair Share, media audiovisual

\section{PENDAHULUAN}

Pembelajaran bahasa memiliki fungsi sebagai sarana untuk meningkatkan kemampuan berpikir, mengungkapkan gagasan, menyampaikan informasi tentang suatu peristiwa, dan untuk memperluas wawasan. Pembelajaran bahasa dan sastra Indonesia juga bertujuan meningkatkan dan mengembangkan keterampilan berbahasa dan bersastra siswa yang berupa keterampilan membaca, berbicara, menyimak, dan menulis. Tarigan (2008) menyatakan bahwa setiap keterampilan tersebut saling berkaitan antara satu dengan yang lain dengan cara yang beraneka ragam. Menulis ialah keterampilan untuk berkomunikasi secara tidak langsung dan merupakan jenis keterampilan produktif dan ekspresif (Tarigan, 2008). Keterampilan ini sangat penting bagi pengembangan diri siswa, baik untuk melanjutkan studi ke lembaga pendidikan lebih tinggi ataupun untuk terjun ke masyarakat. Oleh karena itu, keterampilan menulis sangat penting diajarkan di berbagai jenjang pendidikan. Salah satu keterampilan yang diajarkan di SMA yakni menulis paragraf argumentasi untuk kelas $X$ semester II.

Teks argumentasi merupakan paragraf untuk mempengaruhi sikap dan pendapat orang lain agar pembaca percaya dan akhirnya bertindak sesuai dengan apa yang diinginkan oleh penulis (Keraf, 2010). Mengapa menulis argumentasi itu penting? Menurut Atmazaki (2007), argumentasi digunakan untuk meyakinkan pembaca atau pendengar tentang gagasan yang dikemukakan. Pada dasarnya, argumentasi termasuk bidang retorika atau kemampuan berbahasa yang memberikan keyakinan kepada pendengar atau pembaca berdasarkan alasan (argumen) yang tepat. Alasan itu berasal dari fakta dan hubungan logis antara fakta dengan fakta atau antara fakta dengan pendapat. Menurut Kakan-dee dan Kaur (2015) melalui argumentasi, penulis berusaha menyusun bukti-bukti sehingga dapat ditunjukkan apakah suatu pendapat tertentu itu benar atau tidak. Itulah alasan bahwa siswa harus memiliki keterampilan menulis argumentasi.

Pembelajaran menulis argumentasi merupakan salah satu aspek yang diajarkan di SMA dan kegiatan yang diharapkan antara lain: (1) mendaftar topik-topik yang dapat dikembangkan menjadi paragraf argumentasi; (2) menyusun kerangka paragraf argumentasi; (3) mengembangkan kerangka yang telah disusun menjadi paragraf argumentasi yang utuh; (4) menggunakan kata penghubung antarklausa dalam paragraf argumentasi; dan (5) menyunting paragraf argumentasi yang ditulis teman. Semua rangkaian kegiatan tersebut harus dilaksanakan oleh siswa. Aspek yang dinilai berupa keaslian dan kelogisan opini, kelengkapan fakta, isi karangan, kelengkapan struktur karangan, dan bahasa dan tata tulis (Abidin, 2013).

Namun, praktiknya masih terdapat banyak kendala dalam pembelajaran menulis dan hasilnya belum sesuai dengan harapan. Fenomena tersebut terjadi pada pembelajaran menulis argumentasi di SMA Negeri Kebakkramat. Survei awal menunjukkan bahwa kualitas proses pembelajaran dan keterampilan menulis argumentasi siswa kelas X-10 tergolong rendah. Kualitas proses pembelajaran merupakan perubahan perilaku dalam diri individu dengan 
mencapai suatu keunggulan hasil. Proses pembelajaran merupakan proses yang mendasar dari aktivitas pendidikan di sekolah. Dengan demikian, untuk mendapatkan hasil yang baik maka proses belajar mengajar harus dikelola dengan baik pula. Adanya kualitas proses pembelajaran dapat diketahui dengan melakukan penilaian. Penilaian adalah proses memberikan atau menentukan nilai kepada objek tertentu berdasarkan suatu kriteria tertentu (Sudjana, 2008).

Rendahnya nilai dibuktikan dengan siswa yang lulus tes menulis argumentasi hanya 13 siswa $(34,21 \%)$ dan 25 siswa $(65,79 \%)$ lainnya belum mencapai batas KKM yaitu 75 . Nilai ratarata kelas adalah 66,08 yang termasuk kategori cukup. Hal tersebut dikarenakan kualitas proses pembelajaran yang masih rendah. Berdasarkan observasi dan wawancara, rendahnya keterampilan menulis argumentasi siswa disebabkan: (1) guru masih menggunakan metode konvensional; (2) keaktifan dan movitasi siswa selama pembelajaran menulis argumentasi masih kurang; (3) siswa kurang mampu mengungkapkan faktafakta pendukung yang dijadikan sebagai penguat argumen mereka; (4) kurangnya sumber inspirasi dalam menulis sehingga berdampak pada hasil tulisan siswa; dan (5) siswa kurang paham tentang kaidah tata bahasa yang baik dan benar. Hal tersebut ditegaskan Darmayanti (2014) yang menemukan bahwa akibat rendahnya kemampuan siswa dalam menulis argumentasi tidak terlepas dari peran guru dalam pembelajaran. Guru memberikan materi dan informasi kepada siswa secara langsung yang bersifat tradisional. Akibatnya, siswa tidak kreatif dan terpaku pada hal yang disampaikan guru.

Perlu adanya pembinaan dan pengembangan dalam keterampilan menulis argumentasi pada siswa yakni kreativitas guru dalam menggunakan metode dan media pembelajaran. Pemilihan metode mengajar guru yang kurang variatif dan inovatif berdampak pada kualitas proses dan hasil belajar. Tina, Rangga, Gani, dan Nursaid
(2013) membuktikan bahwa keterampilan menulis argumentasi dapat ditingkatkan dengan penerapan model pembelajaran brainstorming. Oleh karena itu, penelitian ini perlu metode yang lebih inovatif dan menarik yakni model Think Pair Share. Sumarni (2016) mengungkapkan dampak penerapan model TPS, "Think Pair Share is a cooperative learning method that gives students time to think and respond and help each other, by which time the thought be a powerful factor in improving students' ability to respond to questions. "Model ini membantu menciptakan suasana pembelajaran yang lebih aktif, kreatif, efektif, menyenangkan dan secara langsung membantu siswa dapat memahami suatu masalah dan memecahkannya dengan diskusi kelompok dan mempresentasikan hasilnya sebagai bentuk evaluasi.

Guru juga perlu menggunakan media pembelajaran yang tepat, yakni menyesuaikan kondisi perkembangan dan pemahaman siswa. Pada penelitian ini, cara tepat meningkatkan keterampilan menulis argumentasi dengan memanfaatkan media yang lebih inovatif yaitu audiovisual. Menurut Dike (dalam Ode, 2014), sumber audiovisual bukan hanya meningkatkan motivasi guru dan peserta didik melainkan juga dapat menambah kejelasan topik yang diajarkan dan membuat belajar lebih menarik. Model pembelajaran dengan media tersebut yang diterapkan dalam pembelajaran menulis argumentasi sekaligus untuk meningkatkan proses dan hasil pembelajaran. Saddhono (2016) dalam penelitiannya membuktikan bahwa implementasi pembelajaran kooperatif dapat meningkatkan kualitas proses dan keterampilan menulis argumentasi pada mahasiswa BIPA UNS. Berbeda dengan penelitian ini yang fokus pada peningkatan proses hasil keterampilan menulis argumentasi dengan penerapan model Think Pair Share dengan media audiovisual pada siswa SMA.

Pembelajaran menulis argumentasi dalam penelitian ini untuk melatih keterampilan siswa 
dalam menulis argumentasi dengan baik dan benar, serta sesuai dengan kaidah penulisan argumentasi. Ada dua aspek penilaian yakni dari kinerja guru yang meliputi: prapembelajaran, kegiatan pendahuluan, kegiatan inti, dan kegiatan penutup. Serta kinerja siswa yang meliputi aspek: (a) keaktifan siswa selama pembelajaran; (b) perhatian dan konsentrasi siswa selama pembelajaran; (c) minat dan motivasi dalam mengikuti pembelajaran; dan (d) keterlibatan siswa dalam pembelajaran.

Berdasarkan pemikiran di atas, permasalahan yang dikemukakan, yakni: (1) apakah penerapan model pembelajaran Think Pair Share dengan media audiovisual dapat meningkatkan kualitas proses pembelajaran keterampilan menulis argumentasi pada siswa kelas X-10 SMA Negeri Kebakkramat?; dan (2) apakah penerapan model pembelajaran Think Pair Share dengan media audiovisual dapat meningkatkan keterampilan menulis argumentasi pada siswa kelas X-10 SMA Negeri Kebakkramat? Dari rumusan masalah tersebut, tujuan penelitian yakni: (1) kualitas proses pembelajaran keterampilan menulis argumentasi siswa kelas X-10 SMA Negeri Kebakkramat melalui penerapan model pembelajaran Think Pair Share (TPS) dengan media audiovisual; dan (2) keterampilan menulis argumentasi siswa kelas $\mathrm{X}-10$ SMA Negeri Kebakkramat tahun ajaran 2015/ 2016 melalui penerapan model pembelajaran Think Pair Share (TPS) dengan media audiovisual.

Hipotesis tindakan penelitian ini ialah penerapan model pembelajaran Think Pair Share dengan media audiovisual dapat meningkatkan kualitas proses pembelajaran keterampilan menulis argumentasi siswa kelas X-10 SMA Negeri Kebakkramat dan penerapan model pembelajaran Think Pair Share dengan media audiovisual dapat meningkatkan keterampilan menulis argumentasi siswa kelas X-10 SMA Negeri Kebakkramat.

\section{METODE}

Penelitian ini merupakan jenis penelitian kualitatif melalui strategi Penelitian Tindakan Kelas (PTK) dengan dua siklus. Tempat penelitian dilakukan di kelas X-10 SMA Negeri Kebakkramat. Waktu penelitian dilakukan selama 5 bulan, yakni Desember 2015 hingga April 2016. Data yang digunakan dalam penelitian ada dua, yaitu data kualitas proses pembelajaran menulis argumentasi baik kinerja guru maupun kinerja siswa dan data keterampilan menulis argumentasi pada siswa kelas X-10. Sumber data berupa tempat dan peristiwa proses pembelajaran menulis argumentasi, informan, dan dokumen. Teknik pengumpulan data dalam penelitian ini yaitu terdiri dari observasi, wawancara, dan analisis dokumen (tes).

Uji validitas yang digunakan yaitu triangulasi sumber data, triangulasi metode, dan review informan. Teknik analisis data untuk menganalisis data yang telah dikumpulkan melalui teknik deskriptif komparatif (constant comparative method) (Glaser \& Strauss, 2006). Prosedur penelitian mencakup dua siklus melalui beberapa tahapan (Arikunto, Suhardjono \& Supardi, 2015), yakni: 1) perencanaan tindakan (planning), 2) pelaksanaan tindakan (acting), 3) observasi dan interpretasi (observing), 4) analisis dan refleksi (reflecting).

Adapun prosedur penelitian yakni perencanaan tindakan berupa survei awal tentang pembelajaran menulis kelas X-10 SMA Negeri Kebakkramat. Survei awal tersebut dilakukan dengan menganalisis hasil nilai menulis siswa dan melakukan pengamatan secara langsung mengenai proses pembelajaran di dalam kelas. Proses pembelajaran yang diamati yaitu pembelajaran menulis argumentasi; mengidentifikasi dan menganalisis penyebab timbulnya masalah dalam proses pembelajaran menulis yang terdapat di kelas X-10 SMA Negeri Kebakkramat; mengajukan alternatif tindakan untuk mengatasi masalah yaitu berupa penerapan model pembelajaran Think Pair Share 
dengan media audiovisual; menyusun jadwal penelitian dan rancangan pelaksanan tindakan; dan mempersiapkan instrumen penelitian.

Tahap pelaksanaan tindakan mencakup perencanaan tindakan berupa penyusunan Rencana Pelaksanaan Pembelajaran (RPP) dan menyiapkan instrumen penelitian seperti lembar observasi siswa dan rubrik penilaian keterampilan menulis argumentasi. Dalam tahap pelaksanaan tindakan mencakup realisasi RPP dalam siklus I yang dilaksanakan di kelas $\mathrm{X}-10$ selama dua kali pertemuan pada mata pelajaran Bahasa Indonesia. Pada tahap observasi dan interpretasi berupa pengamatan terhadap penerapan model pembelajaran Think Pair Share dengan penggunaan media audiovisual pada proses pembelajaran keterampilan menulis argumentasi. Langkah ini dilakukan dengan mengamati kemudian menginterpretasikan kegiatan menulis argumentasi melalui penerapan model pembelajaran Think Pair Share dengan penggunaan media audiovisual. Terakhir, tahap analisis dan refleksi yaitu menganalisis hasil observasi dan penilaian terhadap kinerja siswa untuk merencanakan siklus berikutnya. Pada tahap ini menganalisis apakah tindakan yang diterapkan sudah dapat mengatasi masalah menulis siswa. Selain itu, mengumpulkan data-data yang nantinya diolah untuk menentukan tindakan yang akan dilakukan selanjutnya.

Dilanjutkan tahap observasi, peneliti bertindak sebagai partisipan pasif yang mengamati dan mencatat proses pelaksanaan tindakan yang dilakukan. Setelah itu, peneliti mengolah data untuk mengetahui apakah tindakan yang dilakukan telah dapat mengatasi masalah yang muncul.

Tahap berikutnya merupakan tahap refleksi yang dilakukan dengan menganalisis atau mengolah data hasil observasi dan interpretasi untuk mengetahui sejauh mana tercapaian tujuan yang diinginkan. Dengan demikian, dapat dilihat apakah penelitian itu berhasil atau tidak dan untuk mengetahui kebaikan dan kelemahan tindakan yang telah dilakukan. Kegiatan refleksi dilakukan dengan diskusi antara peneliti dengan guru terkait hasil observasi dan penilaian terhadap pembelajaran menulis argumentasi. Peneliti dan guru mengadakan diskusi untuk menentukan langkah-langkah perbaikan (solusi pemecahan masalah yang dihadapi dalam pelaksanaan tindakan yang telah dilakukan). Setelah itu, dapat ditarik simpulan apakah penelitian yang dilakukan berhasil atau tidak sehingga dapat menentukan langkah berikutnya.

Adapun indikator keberhasilan pada kualitas proses pembelajaran menulis argumentasi, yakni: kinerja guru; nilai rata-rata mencapai nilai 80 dengan kriteria baik dan kinerja siswa; nilai ratarata 70 dengan kriteria baik; serta keterampilan menulis argumentasi rata-rata 80 dengan kriteria baik. Indikator keberhasilan pada keterampilan menulis argumentasi siswa (kesesuaian dalam aspek keaslian dan kelogisan opini, kelengkapan fakta, isi karangan, kelengkapan struktur, serta bahasa dan tata penulisan) sebanyak 75\% dari jumlah siswa.

\section{HASIL DAN PEMBAHASAN}

Berdasarkan hasil observasi dan wawancara dengan guru dan siswa, diketahui bahwa pembelajaran menulis argumentasi di kelas $X$ 10 masih dilakukan secara konvensional dan berdampak pada rendahnya nilai. Hal ini dibuktikan dengan rata-rata nilai keterampilan menulis argumentasi kelas $\mathrm{X}-10$ sebelum tindakan sebesar 66,08 . Nilai rata-rata tersebut masih di bawah nilai Kriteria Ketuntasan Minimal (KKM), yaitu 75. Diketahui bahwa siswa yang memiliki nilai $\geq$ KKM sebanyak 13 siswa $(34,21 \%)$, sedangkan 25 siswa $(65,79 \%)$ memperoleh nilai $<75$. Dengan demikian, kriteria ketuntasan belum memenuhi indikator pencapaian.

Selanjutnya dilakukan tindakan siklus I, yaitu dengan diterapkannya model pembelajaran Think Pair Share dengan media audiovisual untuk meningkatkan keterampilan menulis argumentasi siswa. Nilai keterampilan menulis argumentasi 
siswa pada siklus I sudah menunjukkan peningkatan dibandingkan pada prasiklus. Siswa kelas $\mathrm{X}-10$ yang memperoleh nilai menulis argumentasi $\geq 75$ (lebih besar atau sama dengan 75) hanya sebanyak 21 siswa saja. Siswa yang tuntas belum mencapai $75 \%$ dari 36 siswa di kelas X-10. Artinya, pada siklus I dianggap belum memenuhi indikator pencapaian. Dengan demikian, perlu dilakukan tindakan siklus II.

Nilai akhir tes siswa pada siklus II sudah cukup memuaskan meskipun tidak mencapai $100 \%$ dan masih terdapat 7 siswa yang belum mencapai KKM. Namun, penelitian dianggap sudah mampu meningkatkan motivasi dan keaktifan siswa keterampilan siswa dalam menulis argumentasi. Dengan demikian, penelitian ini tidak perlu dilanjutkan pada siklus III. Berdasarkan pengamatan dan analisis data yang telah diperoleh, yakni kelas X-10 terkondisikan dengan baik yang memunculkan atmosfer belajar mengajar yang lebih aktif dan bermakna setelah diberi tindakan. Dengan demikian dapat dinyatakan bahwa secara umum terdapat peningkatan kualitas proses pembelajaran dan keterampilan menulis argumentasi siswa kelas X-10 SMA Negeri Kebakkramat dengan menerapkan model Think Pair Share dengan media audiovisual.

Hasil dari tindakan penerapan model Think Pair Share dengan media audiovisual yang dilaksanakan dalam 2 siklus mampu meningkatkan kualitas proses pembelajaran menulis argumentasi siswa kelas $\mathrm{X}-10$ SMA Negeri Kebakkramat. Kinerja guru dan siswa selama proses pembelajaran menulis argumentasi mengalami peningkatan. Indikator penilaian kinerja guru mengadaptasi dari Sudjana (2008) berupa pelaksanaan prapembelajaran, membuka pelajaran, menggali pengetahuan siswa, menyajikan materi pembelajaran, menggunakan media, membimbing diskusi, membimbing siswa presentasi, menguatkan siswa, dan menutup pelajaran.
Adapun data indikator kinerja guru berupa melaksanakan prapembelajaran (persiapan ruang, sumber belajar, memeriksa kehadiran dan kesiapan siswa); membuka pelajaran (melakukan apersepsi, menyampaikan kompetensi dan tujuan yang akan dicapai serta rencana kegiatan dengan jelas, memberikan motivasi kepada siswa); menggali pengetahuan siswa (mengaitkan materi dan permasalahan dengan kehidupan sehari-hari dan pengalaman siswa); menyajikan materi pembelajaran (menyampaikan materi sesuai RPP, menerangkan materi dengan bahasa yang jelas dan mudah dipahami, menggunakan media sesuai materi dan kondisi siswa); keterampilan menggunakan media audiovisual (aplikatif dan inovatif, memberi kesempatan siswa untuk berpartisipasi, menjelaskan instruksi dengan jelas); keterampilan menerapkan model Think Pair Share (membagi kelompok dengan jelas, mengatur tempat duduk, membimbing siswa, menguasai kelas); membimbing siswa dalam diskusi (meyakinkan hasil tulisan siswa, memberi kesempatan tiap kelompok untuk bertanya, memberi motivasi agar siswa aktif, menegur siswa yang beraktivitas di luar diskusi); memberi penguatan kepada siswa (memberi penguatan verbal, apresiasi dan merespon positif hasil kerja siswa); menutup pelajaran (merefleksi kinerja siswa dan melaksanakan tindak lanjut, serta mengelola waktu dengan baik).

Kualitas kinerja guru dikatakan meningkat sebab pada proses pembelajaran prasiklus hanya memperoleh nilai 54,29, lalu meningkat menjadi 69,29 pada siklus I dan pada siklus II meningkat menjadi 80,71 (Gambar 1).

Penilaian kualitas proses pembelajaran juga mencakup penilaian kinerja siswa dalam pembelajaran menulis argumentasi yang difokuskan dalam empat aspek, yaitu (1) keaktifan siswa, (2) perhatian dan konsentrasi siswa, (3) minat dan motivasi siswa, dan (4) keterlibatan siswa dalam pembelajaran. Hasil yang didapatkan bahwa kinerja siswa mengalami 


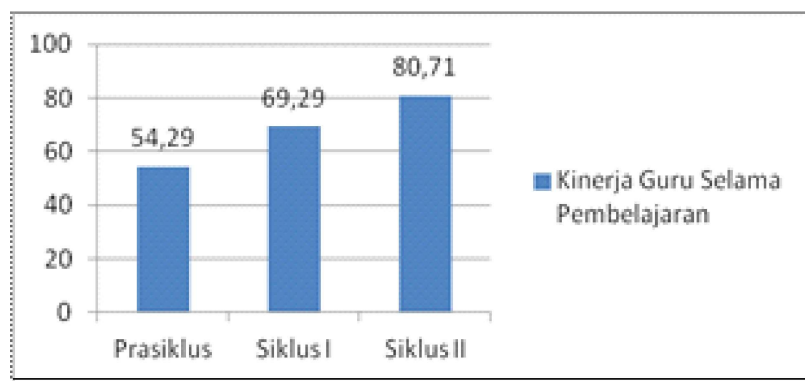

Gambar 1 Diagram Peningkatan Nilai Kinerja Guru dalam Proses Pembelajaran

peningkatan selama proses pembelajaran menulis argumentasi. Pada prasiklus hanya terdapat 28,95\% dengan 11 siswa masuk kategori baik, 19 siswa kategori cukup dan 8 siswa kategori kurang. Lalu meningkat pada siklus I mencapai $58,57 \%$ dengan siswa sebanyak 17 termasuk kategori cukup dan 17 siswa kategori kurang. Pada siklus II kinerja siswa meningkat dan menjadi 78,95\% dengan 30 siswa termasuk kategori baik dan 8 siswa kategori cukup (Gambar 2).

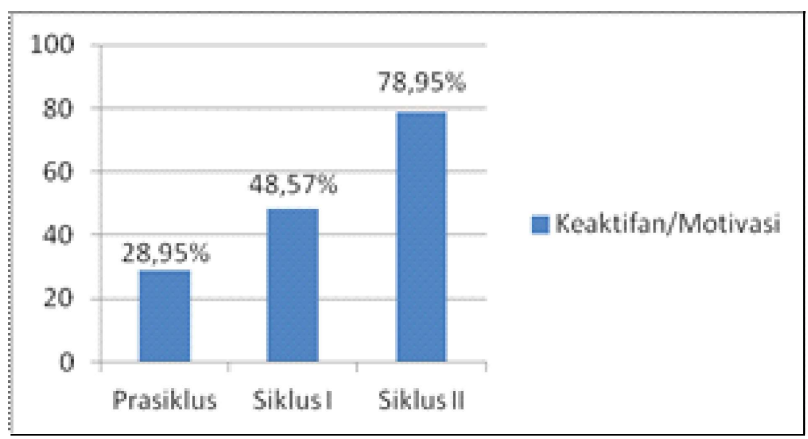

Gambar 2 Diagram Peningkatan Nilai Kinerja Siswa dalam Proses Pembelajaran Menulis Argumentasi

Selain penilaian selama proses pembelajaran dilihat dari aspek kinerja guru maupun aspek kinerja siswa, hasil kerja dari keterampilan menulis argumentasi siswa juga mengalami peningkatan. Diketahui nilai rata-rata kelas sebesar 66,08 dan masih jauh dari KKM yang ditetapkan yaitu $\geq 75$. Pembelajaran siklus I yang menerapkan model pembelajaran Think Pair Share dengan media audiovisual menunjukkan adanya peningkatan keterampilan menulis argumentasi siswa. Ketuntasan keterampilan menulis argumentasi siswa menjadi 58,33\% dibandingkan dengan hasil prasiklus dengan jumlah siswa yang tuntas sebanyak 21 siswa. Pada siklus II terjadi peningkatan yang signifikan dari siklus I. Data keterampilan menulis argumentasi yaitu, siswa yang telah mencapai KKM sejumlah 31 siswa $(81,58 \%)$ dengan ratarata kelas sebesar 80,47 .

Peningkatan yang terjadi dalam siklus I dan II dalam penelitian ini merupakan dampak dari perubahan kinerja siswa dalam mengikuti pembelajaran. Berkaitan dengan peningkatan kualitas proses pembelajaran keterampilan menulis argumentasi dan peningkatan hasil keterampilan menulis argumentasi siswa, berikut disajikan grafik peningkatan tiap siklus keterampilan menulis argumentasi (Gambar 3).

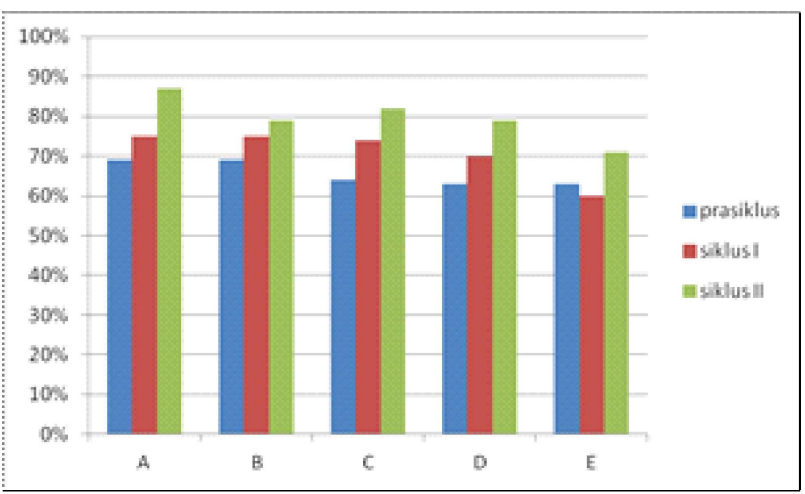

Gambar 3 Grafik Peningkatan indikator keterampilan menulis argumentasi tiap siklus

\section{Keterangan:}
A : Keaslian dan kelogisan opini
B : Kelengkapan fakta
C : Isi karangan
D : Kelengkapan struktur karangan
E : Bahasa dan tata tulis

Untuk melihat perbandingan peningkatan jumlah siswa yang aktif dan hasil keterampilan siswa dalam menulis karangan argumentasi secara jelas dari masing-masing siklus (dapat dilihat pada Gambar 4).

Aspek kinerja siswa dan keterampilan menulis argumentasi siswa dari prasiklus, siklus I, sampai siklus II terdapat peningkatan secara signifikan. Dengan demikian, dapat dikatakan 


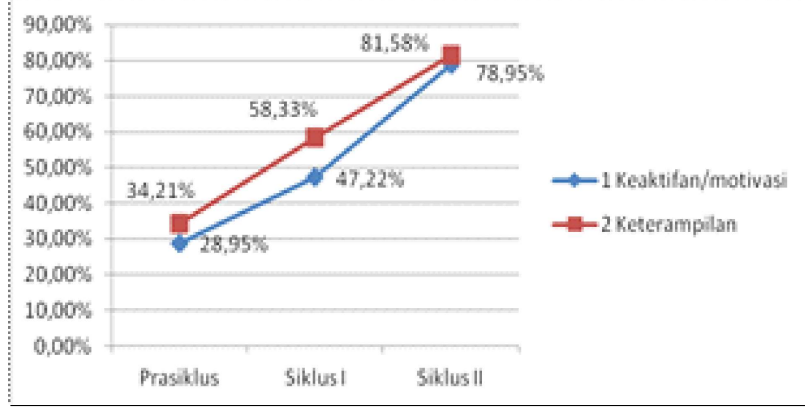

Gambar 4 Grafik Peningkatan Indikator tiap Siklus

bahwa penerapan model pembelajaran Think Pair Share dengan media audiovisual dapat meningkatkan kualitas proses pembelajaran keterampilan menulis argumentasi siswa kelas X-10 SMA Negeri Kebakkramat. Penerapan model pembelajaran Think Pair Share dengan media audiovisual dapat meningkatkan keterampilan menulis argumentasi siswa kelas X-10 SMA Negeri Kebakkramat.

Argumentasi berperan penting dalam pengembangan berpikir kritis dan mengembangkan pemahaman yang mendalam tentang isu-isu kompleks dan ide-ide (Deane \& Yi Song, 2014). Semi (2009) menyebutkan argumentasi bertujuan meyakinkan atau membujuk pembaca tentang kebenaran berpendapat atau pernyataan dari penulis. Amogne (2013) menjelaskan bahwa argumentasi memiliki tujuan yang unik jika dibandingkan dengan genre lain. Pemilihan kosa kata dan preferensi gramatikal juga dapat bergantung pada sifat teks yang dipertanyakan secara umum dan tujuan komunikasinya.

Pada permasalahan yang telah dipaparkan, menulis argumentasi bagi siswa SMA memanglah tidak mudah. Dalam hasil penelitian yang menerapkan model Think Pair Share dengan media audiovisual dianggap mampu meningkatkan keterampilan menulis argumentasi. Metode pembelajaran yang baik dan diterapkan dengan benar akan menghasilkan kualitas proses dan hasil pembelajaran yang baik pula. Peningkatan indikator setiap siklus membuktikan bahwa pemilihan metode yang tepat dapat mengatasi kesulitan belajar yang dialami oleh siswa. Kesulitan yang dialami oleh siswa kelas X-10 SMA Negeri Kebakkramat dalam pembelajaran menulis, yaitu kesulitan menyampaikan dan mengembangkan gagasannya melalui tulisan. Metode khusus dibantu media yang mendorong siswa berpikir lebih jelas dan nyata diperlukan sehingga dapat membantu siswa dalam mengatasi kesulitan tersebut. Penerapan model dengan media tersebut terbukti mampu membantu siswa dalam mengembangkan ide dan gagasan siswa. Hal tersebut terlihat dari hasil pekerjaan siswa yang mengalami peningkatan pada tiap siklusnya.

Sejalan dengan pendapat Ode (2014) yang beranggapan bahwa proses pengajaran dan pembelajaran sangat penting di semua tingkat perkembangan pendidikan. Jika terencana dan terarah dengan baik, maka menjadi kunci keberhasilan dan kemajuan seorang individu. Penerapan model pembelajaran Think Pair Share dengan media audiovisual membuat siswa menjadi lebih aktif dan senang dalam mengikuti kegiatan pembelajaran. Siswa dapat melatih kemandiriannya dalam berpikir untuk menyelesaikan permasalahan berdasarkan objek media yang digunakan dan dapat belajar secara bekerja sama dengan pasangan diskusi. Didukung oleh Sanjaya, Dedi dan Sumarsih (2013) yang mengemukakan bahwa siswa memberi respons dan bersikap baik saat pembelajaran menulis deskripsi berlangsung. Dapat disimpulkan bahwa Think Pair Share mampu meningkatkan prestasi siswa.

McTighe dan Lyman (1988) sebagai pencetus model Think Pair Share berpendapat bahwa model tersebut merupakan model diskusi di mana siswa mendengarkan pertanyaan atau presentasi, lalu memiliki waktu untuk memikirkan secara individual, dilanjutkan diskusi dalam pasangan, dan terakhir berbagi tanggapan dengan kelompok yang lebih besar ke seluruh kelas. Adapun langkah-langkah Think Pair Share dalam penelitian ini dilaksanakan sebagai 
berikut. (1) guru memberikan pertanyaan kepada seluruh siswa dalam kelas; (2) siswa diminta memikirkan sebuah jawaban mengenai pertanyaan dari guru secara individual; (3) siswa berpasangan dengan temannya untuk mencapai sebuah kesepakatan atas jawaban mereka sebelumnya pada tahapan berpikir; dan (4) guru meminta siswa untuk berbagi jawaban yang telah disepakati bersama pasangannya dengan seluruh kelas. Model Think Pair Share merupakan bagian dari pembelajaran kooperatif. Gillies dan Boyle (2010) mengemukakan dalam penelitiannya bahwa cooperative learning bermanfaat dalam pembelajaran. Salah satunya dapat membantu siswa dapat lebih mengatur dan menyusun pelajaran mereka dengan baik. Hal tersebut dibuktikan Lucena dan Jose (2016) bahwa cooperative learning dapat meningkatkan keterampilan berbahasa lainnya seperti berbicara yang juga merupakan keterampilan produktif.

Hasil peningkatan keterampilan menulis argumentasi melalui penerapan Think Pair Share dengan media audiovisual ini sejalan dengan hasil penelitian yang dilakukan Nurcahyanti, Winarni, dan Budiarto (2015) tentang penerapan model pembelajaran Think Pair Share guna meningkatkan proses dan hasil belajar menulis siswa khususnya pantun. Pada penelitian tersebut terlihat peningkatan nilai rata-rata siswa pada tiap-tiap siklus. Pada siklus I nilai rata-rata siswa meningkat menjadi 71,5 dan pada siklus II nilai rata-rata siswa mencapai 67,8 . Nugraheni (2012) mengungkapkan dalam penelitiannya bahwa Think Pair Share dapat meningkatkan keterampilan berbicara siswa. Hasil yang diperoleh terbukti bahwa sebelum tindakan siswa masih tampak gugup, ragu-ragu, tersendat-sendat, sulit mengingat kata-kata yang tepat, mengulang-ulang kata, malu, grogi, dan canggung pada siswa lain. Mereka menjadi lebih berani setelah dilatih oleh guru dengan menggunakan strategi Think Pair Share. Guru menerapkan pembelajaran kooperatif sehingga siswa dapat bekerja sama secara aktif, melibatkan seluruh siswa serta menciptakan suasana belajar berbeda.

Penelitian ini juga menggunakan audiovisual berupa video animasi sebagai media pembelajaran. Olube (2015) mengemukakan bahwa perangkat audiovisual adalah perangkat keras dan perangkat lunak yang dilalui dengan mendorong dan menjalankan proses belajar, termasuk: film strip, radio, televisi, slide dll. Hasil yang diperoleh, siswa lebih termotivasi, perhatian, dan aktif untuk mengikuti pembelajaran. Keefektifan media audiovisual yang diterapkan dalam pembelajaran sesuai dengan penelitian Ode (2014). Bahkan audiovisual membuat belajar lebih tahan lama karena media tersebut memiliki daya tarik yang lebih dari media lain. Penelitian tersebut mengungkapkan bahwa peserta didik mempertahankan sebagian besar apa yang mereka dengar, lihat, dan rasakan dari apa yang hanya mereka dengar. Hal tersebut sependapat dengan Mcnaught (dalam Ashaver \& Igyuve, 2013) bahwa materi audiovisual sangat berguna dalam mengajar secara instruksional serta membantu presentasi. Ia menekankan bahwa konsistensi presentasi yang diinginkan sangat dipengaruhi kegunaan bahan audiovisual.

Audiovisual memberikan pengalaman jangka lama dan berkontribusi pada kedalaman pembelajaran. Sowntharya (2014) berpendapat dalam penelitiannya bahwa video dianggap efektif dalam pembelajaran sebagai media, khususnya dalam pembelajaran bahasa. Namun, dalam penggunaan media audiovisual juga harus memperhatikan subjek dan kondisi lapangan. Pada penelitian ini secara keseluruhan media audiovisual dapat dioptimalkan walaupun pada siklus I masih terkendala karena sebagian kecil siswa belum fokus dalam memperhatikan video. Notosusanto, Sugiyono, dan Salimi (2013) menegaskan bahwa media audiovisual dapat meningkatkan hasil belajar membaca memindai. Membaca merupakan bentuk keterampilan berbahasa yang bersifat reseptif. Penelitian tersebut mengemukakan media audiovisual 
dapat disesuaikan dengan materi dan kondisi siswa untuk mencapai keberhasilan pembelajaran yang dituju. Kemampuan guru dalam melaksanakan pembelajaran membaca memindai menggunaan media audiovisual pada pembelajaran Bahasa Indonesia kelas $\mathrm{V}$ Sekolah Dasar Negeri 04 Teluk Pakedai juga mengalami peningkatan yang signifikan.

Berdasarkan penelitian sebelumnya, model Think Pair Share dapat diterapkan dalam pembelajaran Bahasa Indonesia khususnya menulis. Media audiovisual jika digunakan dengan tepat dapat membantu siswa dalam memahami materi menulis yang disampaikan. Penerapan model pembelajaran Think Pair Share dengan media audiovisual pada penelitian ini dapat membantu siswa mengembangkan topik dengan baik. Selain itu, siswa menjadi lebih aktif dan termotivasi dalam menulis argumentasi sehingga berpengaruh baik pada kualitas hasil pembelajaran menulis argumentasi.

Selain dapat meningkatkan aspek afektif dan psikomotorik siswa, jenis penelitian tindakan kelas dapat menjadi salah satu sarana guru untuk meningkatkan kompetensi guru. Hal ini sesuai dengan Permendiknas RI Nomor 16 Tahun 2007 berkaitan dengan standar kualifikasi akademik dan kompetensi guru. Pada aspek kompetensi profesional nomor 23 ayat 3 berisi, "Melakukan penelitian tindakan kelas untuk peningkatan keprofesionalan". Dengan demikian, sudah menjadi kewajiban guru untuk meningkatkan kualitasnya dalam pembelajaran melalui pelaksanaan penelitian tindakan kelas.

\section{SIMPULAN DAN SARAN}

\section{Simpulan}

Berdasarkan hasil penelitian, dapat disimpulkan bahwa penerapan model pembelajaran Think Pair Share dengan media audiovisual mampu meningkatkan keterampilan menulis argumentasi pada siswa kelas X-10 SMA Negeri Kebakkramat.
Hal ini dapat dibuktikan dengan meningkatnya beberapa indikator berikut: (1) kemampuan siswa dalam memuat keaslian dan kelogisan opini dalam penulisan argumentasi; (2) kemampuan siswa dalam memuat kelengkapan fakta berupa bukti, fakta kutipan yang mencantumkan sumber kutipan, dan fakta yang mendukung opini/ argumen; (3) kemampuan siswa dalam memuat isi karangan, yang berbentuk karangan argumentasi, isi karangan sesuai dengan tema, dan topik karangan yang dikembangkan secara maksimal sehingga menjadi lengkap; (4) kemampuan siswa dalam memuat kelengkapan struktur karangan yang mengandung bagian pendahuluan, tubuh argumen, dan penutup, serta karangan ditata secara teratur dan lengkap; dan (5) kemampuan siswa dalam menata bahasa dan penulisan berupa ejaan, pemakaian huruf kapital, pemilihan kata, pemakaian tanda baca, dan variasi/jenis, efisiensi dan efektivitas kalimat (koherensi).

\section{Saran}

Berdasarkan data empiris yang ditemukan pada penelitian ini guru dapat mempertimbangkan penerapan model Think Pair Share dalam pembelajaran menulis dan lebih sering memanfaatkan media pembelajaran seperti media audiovisual agar lebih bervariasi dalam menyampaikan materi. Agar siswa lebih tertarik dan mahir menulis harus sering melakukan latihan dengan rutin. Guru perlu memperhatikan waktu praktik menulis lebih banyak dibandingkan memberikan materi. Pihak sekolah diharapkan memotivasi guru agar memperluas wawasan mengenai model pembelajaran inovatif yang dapat mendukung proses pembelajaran di kelas sehingga siswa mendapatkan hasil yang baik. Selain itu, sekolah juga perlu menambah fasilitas dalam mengoptimalkan kegiatan pembelajaran agar dapat mendukung inovasi guru dalam menerapkan metode pembelajaran. 


\section{PUSTAKA ACUAN}

Abidin, Y. (2013). Pembelajaran bahasa berbasis pendidikan karakter. Bandung: Refika Aditama.

Amogne, D. (2013). Enhancing students' writing skills through the genre approach. International Journal of English and Literature, 4(5), 242-248.

Arikunto, S., Suhardjono, \& Supardi. (2015). Penelitian tindakan kelas. Jakarta: Bumi Aksara.

Ashaver, D. \& Mwuse I. (2013). The use of audio-visual materials in the teaching and learning processes in colleges of education in Benue State-Nigeria. Journal of Research \& Method in Education, 1(6),44-55.

Atmazaki. (2007). Kiat-kiat mengarang dan menyunting. Padang: UNP Press.

Darmayanti, I.A.M. (2014). Peningkatan keterampilan menulis paragraf argumentasi melalui pembelajaran berbasis masalah. Jurnal Pendidikan dan Pengajaran, 47 (2-3), 145-154.

Deane, P \& Song, Y. (2014). A case study in principled assessment design: designing assessments to measure and support the development of argumentative reading and writing skills. Psicología Educativa, 20, 99-108.

Gillies, RM. \& Boyle, M. (2010). Teachers' reflections on cooperative learning: issues of implementation. Teaching and Teacher Education Journal, 26, 933-940.

Glaser, BG. \& Strauss, A.L. (2006). The discovery of grounded theory. London: Aldine Transaction Publisher.

Ka-kan-dee, M. \& Kaur, S. (2015). Teaching strategies used by thai efl lecturers to teach argumentative writing. Procedia - Social and Behavioral Sciences on 3rd International Conference on Linguistics, Literature and Culture, 208, 143-156.

Keraf, G. (2010). Argumentasi dan narasi. Jakarta: Gramedia.

Lucena, R.J. \& Jose, A.E. San. (2016). Cooperative learning in enhancing the speaking skills of students: A Phenomenological approach. International Journal of Advanced Multidisciplinary Research, 3(2),67-71.

McTighe, J. \& Lyman, F.T. (1988). Cuing thinking in the classroom: the promise of theoryembedded tools. Educational Leadership, 45 (7), 18-24.

Notosusanto, S. \& Salimi, A. (2013). Peningkatan hasil belajar membaca memindai dengan menggunakan media audiovisual pada siswa kelas $V$ sekolah dasar. Jurnal Pendidikan dan Pembelajaran, 2(7),1-15.

Nugraheni, A.S. (2012). Optimalisasi strategi cooperative learning tipe think-pair-share (TPS) untuk meningkatkan kompetensi berbicara siswa kelas V MI. Jurnal Al-Bidâyah, 4(1), 7792.

Nurcahyanti, N., Winarni, R., \& Budiharto, T. (2015). Penerapan model pembelajaran kooperatif tipe think pair share untuk meningkatkan keterampilan menulis pantun (penelitian tindakan kelas pada siswa kelas IV SDN Candi Ampel Kabupaten Boyolali Tahun Ajaran 2013/ 2014). Jurnal Didaktika Dwija Indria, 3 (4), 1-5.

Ode, E.O. (2014). Impact of audio-visual (AVS) resources on teaching and learning in some selected private secondary schools in makurdi. International Journal of Research in Humanities, Arts and Literature (Impact Journal), 5(2),195-202.

Olube, F.K. (2015). Primary school pupils' response to audio-visual learning process in port- 
harcourt. Journal of Education and Practice, 6(10),118-123.

Peraturan Menteri Pendidikan Nasional RI Nomor 16 Tahun 2007 tentang Standar Kualifikasi Akademik dan Kompetensi Guru.

Saddhono, K. (2016). The argumentative writing skill with multicultural awareness in indonesian language for foreign learners. International Scientific Researches Journal, 72(4),108-116.

Sanjaya, D. \& Sumarsih. (2013). TPS as an effective technique to enhance the students' achievement on writing descriptive text. English Language Teaching, 6(12),106-113.

Semi, M.A. (2009). Menulis efektif. Padang: UNP Press.

Sowntharya, G. \& Muhuntarajan. (2014). Audiovisual media and english learners. International Journal on Recent and Innovation Trends in Computing and Communication, 2(2)384386.

Sudjana, N. (2008). Penilaian hasil proses belajar mengajar. Bandung: Rosda Karya.

Sumarni, S. (2016). Think pair share effect of understanding the concept and achievement. Disampaikan dalam konferensi $2^{\text {nd }}$ international conference on teacher training and education Sebelas Maret University, 2(1),783-787.

Tarigan, H.G. (2008). Menulis: sebagai suatu keterampilan berbahasa. Bandung: Angkasa.

Tina, R., Gani, E., \& Nursaid. (2013). Peningkatan pembelajaran menulis argumentasi melalui model pembelajaran brainstorming. Jurnal Pendidikan Bahasa dan Sastra Indonesia, $1(2), 57-63$. 